\title{
Stability of Norepinephrine Solutions in Normal Saline and 5\% Dextrose in Water
}

\author{
Scott E Walker, Shirley Law, Jill Garland, Esther Fung, and John lazzetta
}

\begin{abstract}
Background: Most previous stability studies for norepinephrine have reported the percentage of drug remaining in IV solutions after only $24 \mathrm{~h}$. No previously published study has evaluated the effect of light on the stability of this drug.

Objective: To evaluate the stability of norepinephrine $(64 \mathrm{mg} / \mathrm{L})$ in either normal saline (NS; $0.9 \%$ sodium chloride) or 5\% dextrose in water (D5W) with storage at either $4^{\circ} \mathrm{C}$ or room temperature $\left(23^{\circ} \mathrm{C}\right)$ in polyvinyl chloride (PVC) bags exposed to or protected from normal room lighting for 2 months.

Methods: Thirty-two PVC bags were prepared, each containing norepinephrine at $64 \mathrm{mg} / \mathrm{L}$; half of the bags had normal saline as the diluent and the other half had D5W. The bags were stored at either $4^{\circ} \mathrm{C}$ or room temperature $\left(23^{\circ} \mathrm{C}\right)$, with protection from or exposure to ambient fluorescent room light. Overall, there were 4 bags for each combination of diluent, temperature, and light condition. The concentration of norepinephrine in each bag was determined by a validated, stability-indicating liquid chromatographic method on study days $0,1,2,3,4,8,9,10,11,14,18,21,23,25,28,30,36,42$, and 61 .
\end{abstract}

Results: Analysis of variance revealed differences in percentage remaining as a function of study day $(p<0.001)$ and light conditions $(p<0.001)$, but not diluent $(p=0.06)$ or storage temperature $(p>0.99)$.

Conclusions: Solutions of norepinephrine $64 \mathrm{mg} / \mathrm{L}$ in NS or D5W can be stored in PVC bags at $4^{\circ} \mathrm{C}$ for up to 61 days with protection from light. This expiry date allows for up to $24 \mathrm{~h}$ storage at $23^{\circ} \mathrm{C}$. Solutions that are not protected from light will retain only $90 \%$ of the initial concentration after storage for 39 days at $4^{\circ} \mathrm{C}$. This storage period could include up to $24 \mathrm{~h}$ at room temperature, without protection from light.

Key words: norepinephrine, drug stability

Can J Hosp Pharm 2010;63(2):113-118

\section{RÉSUMÉ}

Contexte : La majorité des études antérieures sur la stabilité de la norépinéphrine ont rendu compte du pourcentage de médicament résiduel dans les solutions intraveineuses après seulement 24 heures. Aucune étude publiée précédemment n'a évalué l'effet de la lumière sur la stabilité de ce médicament.

Objectif : Évaluer la stabilité de la norépinéphrine $(64 \mathrm{mg} / \mathrm{L})$ préparée dans une solution physiologique salée (SP; chlorure de sodium à $0,9 \%$ ) ou du dextrose à $5 \%$ dans l'eau $(\mathrm{D} 5 \mathrm{E})$ et conservée à $4{ }^{\circ} \mathrm{C}$ ou à la température ambiante $\left(23^{\circ} \mathrm{C}\right)$ dans des sacs de polychlorure de vinyle (PVC) exposés ou protégés de la lumière ambiante normale pendant deux mois.

Méthodes : Trente-deux sacs de PVC ont été préparés, chacun contenant de la norépinéphrine à $64 \mathrm{mg} / \mathrm{L}$, la moitié en utilisant comme diluant de la SP et l'autre moitié, du D5E, Les sacs ont été entreposés soit à $4^{\circ} \mathrm{C}$, soit à la température ambiante $\left(23^{\circ} \mathrm{C}\right)$, protégés de la lumière ou exposés à l'éclairage fluorescent ambiant. Dans l'ensemble, quatre sacs ont été préparés pour chaque combinaison de diluant, de température et de condition d'éclairage. La concentration de norépinéphrine dans chaque sac a été déterminée à l'aide d'une épreuve validée par chromatographie liquide haute performance mesurant la stabilité aux jours $0,1,2,3,4,8$, $9,10,11,14,18,21,23,25,28,30,36,42$ et 61 de l'étude.

Résultats : Une analyse de variance a révélé des différences dans le pourcentage de médicament résiduel, en fonction du jour de l'étude $(p<0,001)$ et des conditions d'éclairage $(p<0,001)$, mais non en fonction du diluant $(p=0,06)$ ou de la température d'entreposage $(p>0,99)$.

Conclusions : Les solutions de norépinéphrine à $64 \mathrm{mg} / \mathrm{L}$ préparées dans de la SP ou du D5E et conservées dans des sacs de PVC peuvent être entreposées à une température de $4^{\circ} \mathrm{C}$ pendant un maximum de 61 jours, protégées de la lumière. Cette durée de conservation permet un entreposage pendant un maximum de 24 heures à une température de $23^{\circ} \mathrm{C}$. Les solutions non protégées de la lumière ne conserveront que 90 $\%$ de la concentration initiale de médicament après avoir été entreposées pendant 39 jours à $4{ }^{\circ} \mathrm{C}$. Cette période d'entreposage peut comprendre un maximum de 24 heures à la température ambiante et non à l'abri de la lumière.

Mots clés : norépinéphrine, stabilité des médicaments

[Traduction par l'éditeur] 


\section{INTRODUCTION}

T The expiry date of medications intended for IV administration following reconstitution or dilution is often limited to about $24 \mathrm{~h}$, even when data on extended stability exist, because of the potential for breaks in sterility and contamination of the product. However, when reconstitution and dilution are carried out in a sterile environment, based on the guidance of USP (United States Pharmacopoeia) Chapter <797> recommendations, it is entirely reasonable to assign beyond-use dates of up to 14 days for low-risk compounded sterile products. ${ }^{1}$ For many drugs, extending the beyond-use date may facilitate admixture in the pharmacy, reduce wastage, ${ }^{2,3}$ and result in significant cost savings.

Norepinephrine is primarily used to restore and maintain blood pressure in a variety of situations. The product monograph for one brand of this drug, Levophed, indicates that it should be administered in solutions containing 5\% dextrose to limit the significant loss of potency through oxidation. ${ }^{4}$ The monograph also indicates that vials should be stored in the shipping carton, with protection from light, but no such caution is indicated for diluted solutions, and no expiry date is offered for diluted solutions. Several investigators have evaluated the stability of norepinephrine in solutions intended for IV administration. ${ }^{5-14}$ The concentrations evaluated were generally $16 \mathrm{mg} / \mathrm{L}$ or lower, although Allwood ${ }^{11}$ and Peddicord and others $^{13}$ evaluated concentrations of $40 \mathrm{mg} / \mathrm{L}$ and $64 \mathrm{mg} / \mathrm{L}$, respectively. Most of these studies reported the percentage remaining after only $24 \mathrm{~h}$, and none evaluated the effect of light.

The objective of this study was to evaluate the stability of a single concentration $(64 \mathrm{mg} / \mathrm{L})$ of norepinephrine diluted in either normal saline (NS; $0.9 \%$ sodium chloride) or $5 \%$ dextrose in water (D5W) and stored for 2 months at either $4^{\circ} \mathrm{C}$ or room temperature $\left(23^{\circ} \mathrm{C}\right)$ with exposure to or protection from normal room lighting.

\section{METHODS}

\section{Liquid Chromatography}

The liquid chromatographic system consisted of an isocratic solvent delivery pump (model P4000, Thermo Separation Products, San Jose, California), which pumped a mixture of acetonitrile (OmniSolv; EMD Chemicals Inc, Gibbstown, New Jersey) and $0.05 \mathrm{M}$ phosphoric acid (catalogue no. P286; Fisher Scientific, Toronto, Ontario) containing $1 \mathrm{mg} / \mathrm{mL}$ of heptane sulfonic acid (catalogue no. H 2766, lot 61K5431; Sigma Aldrich Canada Ltd, Oakville, Ontario) through a $15 \mathrm{~cm} \times 4.6 \mathrm{~mm}$ reversed-phase C-18, 3- $\mu \mathrm{m}$ column (Supelcosil ABZ+Plus, catalogue no. 59194; Supelco, Oakville, Ontario) at $1.0 \mathrm{~mL} / \mathrm{min}$. The ratio of acetonitrile to $0.05 \mathrm{M}$ phosphoric acid was 5:95 and was held constant during each chromatographic run. The samples were introduced into the liquid chromatographic system using an autoinjector (WISP 717-Plus; Waters Scientific, Toronto, Ontario).

The column effluent was monitored with a variablewavelength ultraviolet (UV) detector (UV6000; Thermo Separation Products) at $280 \mathrm{~nm}$. Each signal from the detector was integrated and recorded with a chromatography data system (ChromQuest, version 5.0; Thermo Fisher Scientific Inc). The area under the norepinephrine peak at $280 \mathrm{~nm}$ was subjected to least-squares linear regression, and the actual norepinephrine concentration in each sample was determined by interpolation from the standard curve.

\section{Assay Validation}

Following development of the chromatographic system for norepinephrine, the suitability of this method for use as a stability-indicating assay was tested by accelerating the degradation of norepinephrine. ${ }^{15-17}$ A $10-\mathrm{mL}$ sample of a $40 \mathrm{mg} / \mathrm{L}$ solution of norepinephrine (norepinephrine bitartrate injection USP, Sandoz Canada Inc, Boucherville, Quebec; lot 149812, expiry April 2010) was adjusted to a $\mathrm{pH}$ of 8.264 with $0.5 \mathrm{M}$ sodium hydroxide. A second $10-\mathrm{mL}$ sample of a $40 \mathrm{mg} / \mathrm{L}$ solution of the same lot of norepinephrine was adjusted to $\mathrm{pH} 1.977$ with $0.5 \mathrm{M}$ hydrochloric acid. Each solution was placed in a glass vial in a water bath at $80^{\circ} \mathrm{C}$. Samples were drawn from the vial with the $\mathrm{pH} 8.264$ solution immediately before it was placed in the water bath and at 7 other times $(2,5,10,18,26,31$, and $37 \mathrm{~min})$ over a 37 -min study period. Samples were drawn from the vial with the $\mathrm{pH} 1.977$ solution immediately before it was placed in the water bath and at 10 other times $(7,15,30,63,121,180,248,2763,4553$, and $8513 \mathrm{~min}$ ) over an 8513-min study period (about 142 days). Samples $(10 \mu \mathrm{L})$ were injected directly into the chromatographic system using an autoinjector. The resulting chromatograms were inspected for the appearance of additional peaks, and the norepinephrine peak was compared between samples for changes in concentration, retention time, peak shape, and UV spectral purity (200-320 nm) relative to a fresh, undegraded sample.

Following this first phase of evaluation and validation, the accuracy and reproducibility of standard curves were tested over 5 days, and system suitability criteria (theoretical plates, tailing, and retention time) were developed to ensure consistent chromatographic performance, according to accepted analytical guidelines. ${ }^{18}$ Standard curves were prepared daily by diluting $0.75 \mathrm{~mL}$ of a norepinephrine standard (norepinephrine bitartrate injection USP, Sandoz Canada Inc; lot 149812, expiry April 2010) in $5 \mathrm{~mL}$ of distilled water. This stock solution $(150 \mathrm{mg} / \mathrm{L})$ was further diluted to prepare additional standards with final concentrations of 100, 50, 37.5, 18.75, and $12.5 \mathrm{mg} / \mathrm{L}$. These standards were combined with a blank 
and the stock solution to construct a standard curve. A $10-\mu \mathrm{L}$ sample of each solution was chromatographed in duplicate. Also, 2 quality control samples of norepinephrine (concentrations 25 and $75 \mathrm{mg} / \mathrm{mL}$ ) were chromatographed in duplicate each day, and their concentrations were determined and compared with the known concentrations. Intraday and interday errors were assessed by the coefficients of variation of the peak areas of both quality control samples and standards.

\section{Stability Study}

On study day $0,4 \mathrm{~mL}$ of a $1 \mathrm{mg} / \mathrm{mL}$ solution of norepinephrine (norepinephrine bitartrate injection USP, Sandoz Canada Inc; lot 149812, expiry April 2010) was withdrawn from a vial and further diluted in a 50-mL polyvinyl chloride (PVC) minibag of 5\% D5W (Baxter Corporation, Mississauga, Ontario; lot P230821, expiry June 2010) to prepare 16 minibags with nominal concentrations of $64.5 \mathrm{mg} / \mathrm{L}$ (after consideration of $4 \mathrm{~mL}$ of drug volume and assuming $8 \mathrm{~mL}$ of overfill). This procedure was repeated to prepare 16 samples containing $64.5 \mathrm{mg} / \mathrm{L}$ of norepinephrine in 50-mL PVC minibags of 0.9\% NS (Hospira, Saint-Laurent, Quebec; lot 70011 JT, expiry April 1, 2010).

For each diluent (D5W and NS), 8 minibags were stored at $4^{\circ} \mathrm{C}$ and 8 were stored at room temperature $\left(23^{\circ} \mathrm{C}\right)$. For the bags stored at each temperature, half $(n=4)$ were protected from ambient fluorescent room light (using Amber Zip Bags, $127 \mathrm{~mm} \times 203 \mathrm{~mm}, 3 \mathrm{mil}$; thebagcompany Inc, West Springfield, Massachusetts; obtained through PharmaSystems Inc, Markham, Ontario), and the other 4 were exposed to ambient fluorescent room light. On study days $0,1,2,3,4,8,9,10,11,14,18$, $21,23,25,28,30,36,42$, and 61 , the concentration of norepinephrine was determined in duplicate, as described below, and visual inspection was completed.

On each analysis day, 1-mL samples were drawn from each PVC minibag, and $10-\mu \mathrm{L}$ samples were injected directly into the chromatographic system, in duplicate, without further dilution or preparation.

\section{Data Reduction and Statistical Analysis}

After determination of the coefficient of variation for replicate determinations of concentration for an assay, a power calculation demonstrated that 2 replicates were required to ensure that the analytical method could distinguish between concentrations that differed by at least $10 \% .^{19,20}$ Mean results from different days for each test were compared statistically to determine if there was an association between the observed result and time (linear regression). Analysis of variance (ANOVA) was used to test differences in degradation rate between combinations of temperature, diluent, and concentration. The 5\% level was used as the a priori cutoff for significance. Concentrations were considered "acceptable" or "within acceptable limits" if the concentration was greater than $90 \%$ of the initial (day 0) concentration and the amount found on that day, with $95 \%$ confidence, exceeded $90 \%$ of the initial concentration.

\section{RESULTS}

\section{Accelerated Degradation and Assay Validation}

Degradation of norepinephrine with heat and base $(\mathrm{pH}$ 8.264) occurred relatively quickly, such that less than $1 \%$ of the initial norepinephrine concentration remained after $37 \mathrm{~min}$. As the norepinephrine concentration decreased, degradation products eluted at $1.3,1.7,2.1,2.5,2.8$, and $4.8 \mathrm{~min}$. These degradation products were well separated from norepinephrine, which eluted at $5.5 \mathrm{~min}$ (Figure 1). Degradation appeared to occur in a first-order fashion, with a half-life of $5.5 \mathrm{~min}$ $(r=0.9969, n=8)$. Degradation of norepinephrine with heat and acid ( $\mathrm{pH}$ 1.977) occurred more slowly, such that about $80 \%$ of the initial norepinephrine concentration remained after $142 \mathrm{~h}$. As a result of the chromatographic separation of these degradation products from norepinephrine, and the similarity of the UV spectrum (200-320 nm) between a fresh norepinephrine sample and norepinephrine in a degraded sample, it was concluded that this analytical method was stability-indicating. ${ }^{15-17}$

Assay validation demonstrated that the absolute deviation from the known concentration for quality control samples and standards on any day averaged $2.1 \%$. Replicate error within a day averaged less than $0.6 \%$ for standards and $0.5 \%$ for quality control samples.

Analysis of accuracy and reproducibility during the study period indicated that the norepinephrine concentration was measured accurately and reproducibly. Accuracy, based on the mean of duplicate determinations of standards over the study period, showed that there was less than $1.5 \%$ absolute deviation from the expected concentration. Replicate error within a day (as measured by the coefficient of variation) averaged less than $0.5 \%$ for standards. Between-day variation, as measured by the coefficient of variation in terms of the slope of the standard curve from day to day, averaged $4.2 \%$. This was similar to the observed standard deviation of regression for percent remaining of $3.95 \%$. This result indicates that differences of $10 \%$ or more could be confidently detected with acceptable error rates ${ }^{19,20}$ with duplicate analysis. System suitability criteria were developed on the basis of daily calculations of theoretical plates, tailing, retention time, and accuracy observed during the validation period and were used to ensure continued chromatographic performance during the study period. On each day, the mobile phase was prepared to ensure a retention time for norepinephrine between 4.9 and $5.2 \mathrm{~min}$. 


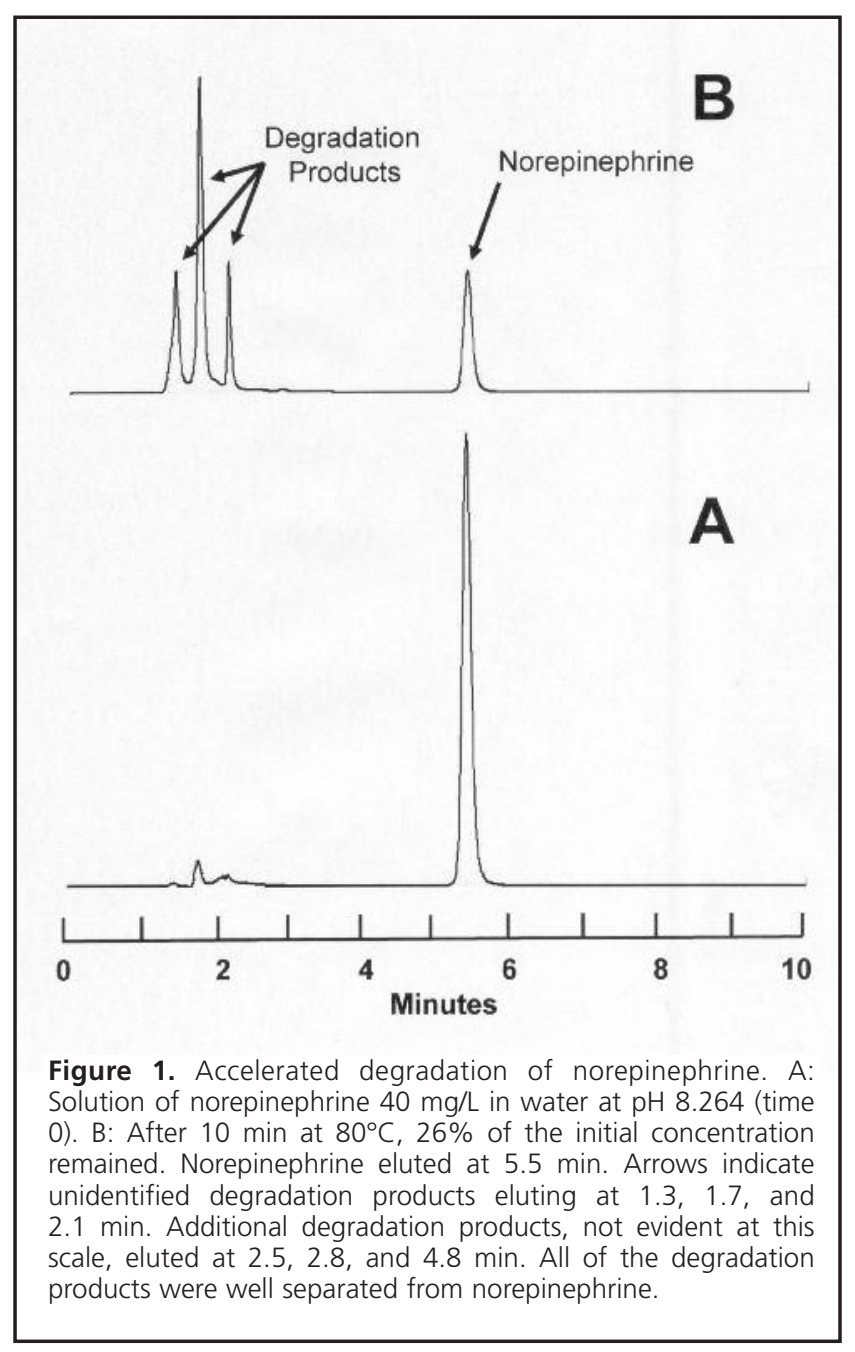

\section{Stability of Norepinephrine}

For each set of storage conditions, the initial concentration and the percent remaining on each study day during the study period is reported (as mean of replicate analyses) in Table 1. Representative chromatograms for D5W solutions on days 0 and 61 showed very small amounts of degradation products (Figure 2).

Analysis of variance revealed differences in percent remaining due to study day $(p<0.001)$ and protection from or exposure to light $(p<0.001)$, but revealed no differences due to diluent $(p=0.06)$ or temperature $(p>0.99)$.

Inspection of the fastest degradation rates observed with 95\% confidence (Table 1) revealed that solutions protected from light had slower degradation rates and took 2 to 8 times longer to reach $90 \%$ of the initial concentration (T-90) than solutions stored without protection from ambient fluorescent light. Inspection of the concentration remaining on day 61 , based on the fast degradation rates with $95 \%$ confidence (Table $1)$, revealed that all solutions stored with protection from light lost between $3.6 \%$ and $12.3 \%$ (mean $6.2 \%$ ) of their initial concentration, regardless of storage temperature. In contrast,

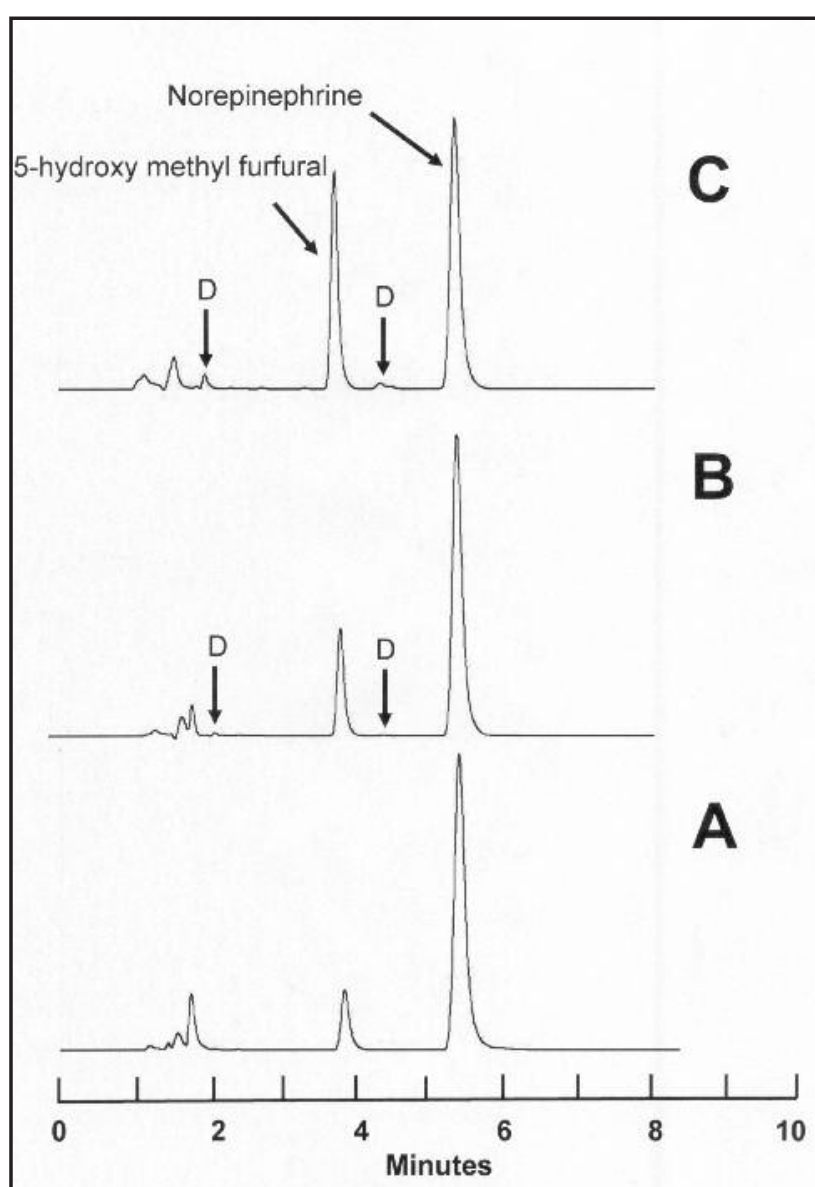

Figure 2. Chromatograms obtained during the 61-day stability study. A: Solution of norepinephrine $64.5 \mathrm{mg} / \mathrm{L}$ in $5 \%$ dextrose in water (D5W) on study day 0 . B: Solution of norepinephrine $64.5 \mathrm{mg} / \mathrm{L}$ in $\mathrm{D} 5 \mathrm{~W}$ after 61 days of storage at $23^{\circ} \mathrm{C}$, protected from light, with undetectable loss. C: Solution of norepinephrine $64.5 \mathrm{mg} / \mathrm{L}$ in D5W after 61 days of storage at $23^{\circ} \mathrm{C}$ with no protection from light; $93 \%$ of the original concentration remains. $\mathrm{D}=$ degradation products (see arrows). These degradation products were identical in retention time with those observed in the accelerated degradation study (Figure 1). It was apparent that 5-hydroxy methyl furfural, a degradation product of dextrose that was observed only in solutions prepared with D5W, increased over the course of the study and increased to a greater extent in solutions that were unprotected from light.

solutions exposed to ambient fluorescent light lost between $10.5 \%$ and $22.6 \%$ (mean $17.4 \%$ ) of their initial concentration.

\section{DISCUSSION}

Based on the fastest degradation rate observed, with $95 \%$ confidence, this study has demonstrated that solutions of norepinephrine, diluted in NS or D5W to a concentration of $64.5 \mathrm{mg} / \mathrm{L}$ and stored for 60 days with protection from light at $4^{\circ} \mathrm{C}$ and then at room temperature for an additional $24 \mathrm{~h}$, will retain more than $95 \%$ of the initial concentration. Solutions that are not protected from light will retain only $90 \%$ of the initial concentration with storage for 39 days at $4^{\circ} \mathrm{C}$. This 
Table 1. Stability of Norepinephrine during Storage, Expressed as Percentage of

Original Concentration Remaining*

\begin{tabular}{|c|c|c|c|c|c|c|c|c|}
\hline \multirow[b]{3}{*}{ Study day } & \multicolumn{4}{|c|}{ D5W } & \multicolumn{4}{|c|}{ NS } \\
\hline & \multicolumn{2}{|c|}{ Protected from Light } & \multicolumn{2}{|c|}{ Exposed to Light } & \multicolumn{2}{|c|}{ Protected from Light } & \multicolumn{2}{|c|}{ Exposed to Light } \\
\hline & RT & $4^{\circ} \mathrm{C}$ & RT & $4^{\circ} \mathrm{C}$ & RT & $4^{\circ} \mathrm{C}$ & RT & $4^{\circ} \mathrm{C}$ \\
\hline \multicolumn{9}{|l|}{ Observed initial } \\
\hline $\begin{array}{l}\text { concentration } \\
\text { (mg/L) }\end{array}$ & 70.06 & 64.46 & 66.18 & 66.67 & 66.79 & 63.26 & 65.29 & 65.84 \\
\hline 0 & 100.00 & 100.00 & 100.00 & 100.00 & 100.00 & 100.00 & 100.00 & 100.00 \\
\hline 1 & 103.20 & 102.71 & 103.49 & 103.22 & 103.35 & 103.16 & 105.16 & 101.92 \\
\hline 2 & 95.85 & 103.94 & 97.59 & 93.97 & 98.28 & 100.24 & 100.04 & 95.03 \\
\hline 3 & 99.79 & 98.50 & 102.79 & 100.16 & 103.20 & 102.62 & 103.26 & 101.80 \\
\hline 4 & 103.25 & 103.61 & 104.35 & 103.54 & 103.67 & 104.66 & 106.36 & 104.02 \\
\hline 8 & 102.97 & 102.00 & 104.49 & 99.63 & 100.31 & 103.79 & 104.70 & 101.79 \\
\hline 9 & 104.37 & 104.39 & 105.89 & 102.15 & 106.53 & 106.21 & 105.70 & 104.60 \\
\hline 10 & 102.19 & 102.12 & 105.22 & 99.56 & 104.82 & 105.16 & 107.32 & 102.23 \\
\hline 11 & 102.82 & 102.43 & 104.74 & 99.53 & 104.72 & 104.96 & 106.93 & 103.30 \\
\hline 14 & 105.61 & 104.90 & 106.02 & 102.46 & 106.75 & 108.16 & 106.01 & 102.14 \\
\hline 18 & 102.67 & 103.39 & 93.46 & 95.68 & 97.14 & $115.62+$ & 96.11 & 98.16 \\
\hline 21 & 101.30 & 99.22 & 91.90 & 92.75 & $110.89+$ & 103.21 & 98.75 & 99.16 \\
\hline 23 & 100.69 & 104.11 & 98.02 & 94.79 & 100.31 & 103.72 & 92.22 & 97.78 \\
\hline 25 & $118.42 †$ & 102.05 & 106.36 & 94.91 & $84.83 \dagger$ & 108.73 & 101.35 & 102.57 \\
\hline 28 & 101.54 & 94.69 & $85.75 \dagger$ & 93.03 & 95.05 & 103.94 & 94.42 & 96.32 \\
\hline 30 & 101.30 & 102.42 & 92.64 & 94.82 & 99.95 & 103.34 & 93.18 & 96.79 \\
\hline 36 & 104.24 & 102.36 & 95.48 & 94.60 & 102.68 & 104.13 & 95.97 & 96.74 \\
\hline 42 & 102.94 & 102.66 & 96.36 & 93.16 & 102.88 & 103.46 & 94.57 & 97.21 \\
\hline 61 & 104.54 & 103.94 & 93.46 & 94.14 & 103.84 & 105.06 & 94.46 & 98.00 \\
\hline \multicolumn{9}{|l|}{$\overline{S D}$ from } \\
\hline $\begin{array}{l}\text { regressiont } \\
\text { Degradation }\end{array}$ & 4.274 & 2.535 & 5.176 & 2.873 & 5.607 & 3.444 & 3.885 & 2.604 \\
\hline $\begin{array}{l}\text { Degradation } \\
\text { rate }(\% / \text { day }) \neq \S\end{array}$ & -0.0596 & -0.0728 & -0.3711 & -0.2485 & -0.2019 & -0.0720 & -0.3486 & -0.1719 \\
\hline T-90 (days)§ף & 167.9 & 137.5 & 26.9 & 40.2 & 49.5 & 138.8 & 28.7 & 58.2 \\
\hline \multicolumn{9}{|l|}{$\%$ remaining§** } \\
\hline Day 14 & 99.2 & 99.0 & 94.8 & 96.5 & 97.2 & 99.0 & 95.1 & 97.6 \\
\hline Day 28 & 98.3 & 98.0 & 89.6 & 93.0 & 94.3 & 99.0 & 90.2 & 95.2 \\
\hline Day 61 & 96.4 & 95.6 & 77.4 & 84.8 & 87.7 & 95.6 & 78.7 & 89.5 \\
\hline
\end{tabular}

$\%$ remaining

with storage

At $4^{\circ} \mathrm{C}$ for

28 days

At $4^{\circ} \mathrm{C}$ for

38 days

93.04

97.98

95.19

For 1 additional

97.23

90.56

97.26

93.47

day at $23^{\circ} \mathrm{C}+\dagger$

97.18††

90.19††

97.06††

$93.12+\dagger$

At $4^{\circ} \mathrm{C}$ for

60 days

95.64

85.09

95.68

89.69

For 1 additional

day at $23^{\circ} \mathrm{C} \dagger$

95.58†十

84.72††

95.48†十

89.34††

$\mathrm{D} 5 \mathrm{~W}=$ dextrose $5 \%$ in water, $\mathrm{NS}=$ normal saline $(0.9 \% \mathrm{NaCl}), \mathrm{RT}=$ room temperature $\left(23^{\circ} \mathrm{C}\right), \mathrm{SD}=$ standard deviation.

* Each value is based on duplicate determination of 3 samples. The percent remaining is based on the observed concentration on day $0(100 \%)$.

tBad chromatography observed. Rather than discard these results, the divergent results are shown. The inclusion of divergent results increases the variability in observed results (note especially the increase in the standard deviation from regression). This ultimately widens the confidence intervals and shortens expiration times and T-90s.

\#Degradation rate was determined by linear regression of percent remaining on each study day.

§Fastest degradation rate and T-90 are based on a lower 95\% confidence limit of the slope determined by regression.

१T-90 is the time for the concentration to change by $10 \%$ based on the degradation rate.

$* *$ Percent remaining, with $95 \%$ confidence, was based on the initial observed concentration (100\%) and the fastest degradation rate as determined by regression.

††Using the fastest observed degradation rates determined by regression ( $95 \%$ confidence interval), calculations are completed for a solution stored under the specified conditions (temperature, solution, and protection from light) for a period of time at $4^{\circ} \mathrm{C}$ as well as an additional $24 \mathrm{~h}$ at room temperature $\left(23^{\circ} \mathrm{C}\right)$. 
storage period could include up to $24 \mathrm{~h}$ of storage at room temperature, without protected from light.

These results are in general agreement with all previously published studies, ${ }^{5-14}$ which have all demonstrated the stability of norepinephrine. Of the papers published in English and reporting results obtained with stability-indicating analytical methods, ${ }^{7,10-14}$ the study duration was relatively short, at only $24 \mathrm{~h},{ }^{10,12,13} 36 \mathrm{~h},{ }^{7}$ or 7 days. ${ }^{14}$ Study duration was not actually specified by Newton and others ${ }^{7}$ but can be inferred from data presented in the report. Similarly, study duration was not specifically mentioned by Allwood, ${ }^{11}$ but appears to have been 30 days. The time to achieve $90 \%$ of initial concentration was reported as 104 days for a $7.17 \mathrm{mg} / \mathrm{L}$ solution ${ }^{7}$ and as 114 days for a $16 \mathrm{mg} / \mathrm{L}$ solution or 174 days for a $40 \mathrm{mg} / \mathrm{L}$ solution protected from light. ${ }^{11}$ Although the data suggested stability for a period in excess of 100 days, Allwood ${ }^{11}$ recommended a shelf-life of only 30 days, a conclusion that may be constrained by the unspecified study duration in that study. ${ }^{11}$ Both Allwood $^{11}$ and Tremblay and others ${ }^{14}$ found that norepinephrine was equally stable in dextrose and in saline solutions, in agreement with this study but in opposition to the product monograph. ${ }^{4}$ In this study, ANOVA revealed no difference in stability due to diluent $(p=0.06)$. Although some might consider this a "trend", we would point out that the time to achieve $90 \%$ of the initial concentration (10\% loss) was 26.9 days with D5W solutions stored without protection from light at room temperature but 28.7 days for the saline solution stored under similar conditions. This nonsignificant difference actually "trends" in the opposite direction from the statements in the product monograph. The product monograph ${ }^{4}$ also indicates that norepinephrine should be protected from light, and we observed that light was the single most significant factor affecting stability, whereas temperature and diluent had no such effect on stability. None of the previously published studies evaluated the effect of light. ${ }^{5-14}$

We conclude that a 61-day expiry date is suitable for $64.5 \mathrm{mg} / \mathrm{L}$ solutions of norepinephrine in D5W or NS, when stored at $4^{\circ} \mathrm{C}$ with protection from light. This expiry date allows for up to $24 \mathrm{~h}$ storage at $23^{\circ} \mathrm{C}$. The expiry dates reported in this study should be used only after due consideration of sterility and the contamination rate in any particular IV additive program.

\section{References}

1. Kastango ES, Bradshaw BD. USP chapter 797: establishing a practice standard for compounding sterile preparations in pharmacy. Am J Health Sys Pharm 2004;61(18):1928-1938.

2. Walker SE, Hanabusa Y, Dranitsaris G, Bartle WR, Iazzetta J. Cost effective evaluation of a stability study. Can J Hosp Pharm 1987;40(4):113-118.

3. Walker SE, DeAngelis C, Iazzetta J, Gafni A. Chemotherapy waste reduction through shelf-life extension. Can J Hosp Pharm 1994;47(1): 15-23.

4. Hospira Healthcare Corp. Levophed ${ }^{\circledR}$ norepinephrine bitartrate [monograph]. In: Repchinsky C, editor. Compendium of pharmaceuticals and specialities. Ottawa (ON): Canadian Pharmacists Association; 2008. p. 1237.

5. Haggendal J. Johnsson G. The stability of noradrenaline in infusion solutions. Acta Pharmacol Toxicol 1967;25(4):461-464.
6. Hughes IE, Smith JA. The stability of noradrenaline in physiological saline solutions. J Pharm Pharmacol 1978;30(2):124-126.

7. Newton DW, Fung EY, Williams DA. Stability of five catecholamines and terbutaline sulfate in 5\% dextrose injection in the absence and presence of aminophylline. Am J Hosp Pharm 1981;38(9):1314-1319.

8. Tokunaga H, Kimura T, Kawamura J. [Studies of stability for $\mathrm{dl}$-norepinephrine in solutions]. Eisei Shikenjo Hokoku [Bull Natl Inst Hyg Sci] 1982;(100):40-43. Japanese, with English abstract.

9. Wollmann H, Grünert R. [The effect of visible light on the stability of isoprenaline, epinephrine and levarterenol solutions in various containers. 86. Problems in the use of plastic containers for liquid preparations. 21. The stability of drugs and preparations]. Pharmazie 1984;39(3):161-163. German, with English abstract.

10. Baumgartner TG, Knudsen AK, Dunn AJ, Kilroy RA. Norepinephrine stability in saline solutions. Hosp Pharm 1988;23:44,49,59.

11. Allwood MC. The stability of four catecholamines in $5 \%$ glucose infusions. J Clin Pharm Ther 1991;16(5):337-340.

12. Grillo JA, Gonzalez ER, Ramaiya A, Karnes HT, Wells B. Chemical compatibility of inotropic and vasoactive agents delivered via a multiple line infusion system. Crit Care Med 1995;23(6):1061-1066.

13. Peddicord TE, Olsen KM, ZumBrunnen TL, Warner DJ, Webb L. Stability of high-concentration dopamine hydrochloride, norepinephrine bitartrate, epinephrine hydrochloride, and nitroglycerin in 5\% dextrose injection. Am J Health Syst Pharm 1997;54(12):1417-1419.

14. Tremblay M, Lessard MR, Trepanier CA, Nicole PC, Nadeau L, Turcotte G. Stability of norepinephrine infusions prepared in dextrose and normal saline solutions. Can J Anaesth 2008;55(3):163-167.

15. Trissel LA. Avoiding common flaws in stability and compatibility studies of injectable drugs. Am J Hosp Pharm 1983;40(7):1159-1160.

16. Trissel LA, Flora KP. Stability studies: five years later. Am J Hosp Pharm 1988;45(7):1569-1571.

17. Policy for publication of chemical stability study manuscripts. Can J Hosp Pharm 1990;43(1):3-4.

18. Shah VP, Midha KK, Dighe S, McGilveray IJ, Skelly JP, Yacobi A, et al. Analytical methods validation: bioavailability, bioequivalence and pharmacokinetic studies. J Pharm Sci 1992;81(3):309-312.

19. Freiman JA, Chalmers TC, Smith H Jr, Kuebler RR. The importance of beta, type II error and sample size in the design and interpretation of the randomized control trial. Survey of 71 "negative" trials. $N$ Engl J Med 1978;299(13):690-694.

20. Stolley PD, Strom BL. Sample size calculations for clinical pharmacology studies. Clin Pharmacol Ther 1986;39(5):489-490.

Scott E Walker, MScPhm, FCSHP, is Co-ordinator, Research and Quality Control, Department of Pharmacy and Division of Pharmacology, Sunnybrook Health Sciences Centre, and Associate Professor, Leslie Dan Faculty of Pharmacy, University of Toronto, Toronto, Ontario.

Shirley Law, DipPharmTech, is a Research Assistant in Quality Control, Department of Pharmacy, Sunnybrook Health Sciences Centre, Toronto, Ontario.

Jill Garland, BScPhm, MSc, is the Pharmacy Operations Leader, Department of Pharmacy, Toronto General Site - University Health Network, Toronto, Ontario.

Esther Fung, BSc, MScPhm, is the Director of Pharmacy Operations, University Health Network, and Lecturer, Leslie Dan Faculty of Pharmacy, University of Toronto, Toronto, Ontario.

John lazzetta, PharmD, is Co-ordinator, Drug Information, Department of Pharmacy and Division of Pharmacology, Sunnybrook Health Sciences Centre, and Assistant Professor, Leslie Dan Faculty of Pharmacy, University of Toronto, Toronto, Ontario.

\section{Address correspondence to:}

Scott E Walker

Co-ordinator, Research and Quality Control

Department of Pharmacy

Sunnybrook Health Sciences Centre

2075 Bayview Avenue

Toronto ON M4N 3M5

e-mail: scott.walker@sunnybrook.ca 